\title{
Same Old Sun, New Shadows: A Postcolonial and Feminist Reading of Yvonne Vera's The Stone Virgins
}

\section{Tshabalala Makhosini ${ }^{1}$ and Kadodo Webster ${ }^{2}$}

${ }^{1}$ Nkosikazi Primary School, Matabeleland North, Zimbabwe

${ }^{2}$ Great Zimbabwe University, Box 1235, Off Great Zimbabwe Ruins Road, School of Education, Department of Curriculum Studies, Masvingo, Zimbabwe.

\section{ABSTRACT}

The article examines the extent to which Vera's The Stone Virgins can be read as a historiography of post-independence Zimbabwe. Some scholars accuse Vera in The Stone Virgins for fanning tribal friction, polarizing the nation and subverting the official war narrative. Our primary purpose is to explore the text to foreground the subtle discursive strategies as the text comments on the national historiography of Zimbabwe as a postcolonial nation-state. The article attempts to ascertain whether the textual narrative is 'like the sun', whether the text candidly offers alternative narrative by way of 'writing in' the elided aspects of the postcolonial experience (telling it blunt), or it subtly negotiates for the right to remember, heal and belong (telling it slant). The present article is therefore guided by two objectives, that is, to explore whether Vera's The Stone Virgins can be regarded as historiography of post-independent Zimbabwe and also to examine whether the novel negotiates for closure and healing or simply opens up old wounds to fan social strife and polarity.

Keywords: historiography, same old sun, new shadows, stone virgins.
*Correspondence to Author:

Kadodo Webster

Great Zimbabwe University, Box 1235, Off Great Zimbabwe Ruins Road, School of Education, Department of Curriculum Studies, Masvingo, Zimbabwe.Cell number $+263776294721 \&+263712939677$

How to cite this article:

Tshabalala Makhosini and Kadodo Webster. Same Old Sun, New Shadows: A Postcolonial and Feminist Reading of Yvonne Vera's The Stone Virgins. American Journal of Educational Research and Reviews, 2018,3:12.

\section{eSciencePublisher 。}

eSciPub LLC, Houston, TX USA. Website: http://escipub.com/ 


\section{Introduction}

Vera's The Stone Virgins has excited quite diverse emotions, with some applauding the writer for venturing off the beaten path and engaging taboo subjects such as the traumatic cost of Zimbabwe's pre- and postindependence era on Africans in general, and womenfolk in particular, especially those in the Midlands and Matabeleland Provinces (Mzali, 2011; Mupondi, 2013). Others, however, accuse Vera's The Stone Virgins of fanning tribal friction with the result that the novel polarizes the nation and subverts the official narrative (Vambe, 2004). Vambe in Veit-Wild (2006:203) notes that;

Vera participates in the reinvention of tribalism and unfortunately, at this point of the narrative, the author's mode of revising the official ZANU PF war narrative is not to step outside stereotyping the new government as callous, through and through. [...]. What the novel elides in this counter narrative is that some Shona people also suffered in the Matabeleland disturbances.

For such minded-likes, Vera, in The Stone Virgins, is viewed as mischievous and rabblerousing to quaint some folk. Contrary to Vambe's (and others') views above, other scholars and people in the communities that bore the brunt of the Gukurahundi activities evoke Adorno's (1983) injunction that aesthetic literary works are never adequately able to capture and present the true horror of the witnesses-cum-victims of atrocities committed in the name of 'dissident insurrections'.

In light of the burden placed on this study as suggested in the title, views like the above call for an analysis of the text and factors motivating the choices of style on the part of the novelist and how these choices affect the quality of her work as commentary on the national narrative. The interrogation of the text is done against the background of the postcolonial nature of Zimbabwe as a nation-state that is characterized by 'enforced' silence and selective amnesia. This is even evidenced by the recent camouflaged coup de tat in Zimbabwe where, in our view, the masses were cannon fodder for the Military's objectives that seem more informed by a need to rejuvenate a particular political party than improve the lot of the majority.

The conflicting character of views on Vera's The Stone Virgins is encapsulated in the title of this article 'Same Old Sun, New Shadows'. The 'sun' in the title for this article is inspired by Narayan's (1943) story 'Like the Sun' in which he likens the truth to the sun since no human being can dare look it 'in the face' without being dazed. We also borrow some ideas from Emily Dickinson's (1924) poem 'Tell all truth but tell it slant', so that 'it dazzles gradually, or it will leave all men blind, for it is too bright for our infirm delight'. We use 'shadows' as in Derida's (1994:7) context in which shadows are seen as 'specters' - mental representations of some haunting experiences; that which seemingly disappeared but insipidly appears still. 'Shadows' is thus synonymous with phantomlike figures lurking in artificial darkness (created by the deliberate gagging of certain narratives) which must be exorcised by the sun (the truth).

\section{Research Questions}

The current research is guided by the following questions.

1. To what extent can Vera's The Stone Virgins be understood as historiography of postindependence Zimbabwe?

2. How far can Vera's The Stone Virgins be seen to either negotiate for closure and healing, or to simply open up old wounds to fan social strife and polarity? 


\section{The Postcolonial theory tinged with Feminism}

Postcolonial criticism adopts close reading of text paying attention to diction, imagery and tropes in order to uncover underlying tensions in power relations. It proceeds under the assumption that colonialism is a powerful, usually destructive, historical force that leaves an indelible mark not only on the identities of the colonized but also of the colonizing peoples as well. The theoretical lens also enjoys privileged knowledge that the success of the colonial project was hinged on the process of 'othering' the colonized. As such, even the new elites are susceptible to harnessing the 'othering' label to sustain their longevity in power. Towards that end, the meta-narrative emerging from the center is likely to be at odds with the classic dictum that literature reflects social life. Quite to the contrary, such narrative tends to refract the actual experiences in the postcolonial space by presenting the world only as seen through the eyes of the elite. Postcolonial criticism also locates the reading of given texts in a particular context to avoid rendering messages deciphered from such texts incidental rather than intentional. The postcolonial critic should necessarily pay close attention to how the subaltern literature subverts the meta-narrative.

A critic enjoying the service of the postcolonial lens pays attention to how the novelist's discursive techniques portray the relations between the former colonizer and the colonized, as well as between the governing and the governed. At every level, the narrative of the postcolonial text needs to be viewed as potentially intended to dismantle some hegemonic view monopolized by the metanarrative. To this end, Ashcroft insists that:

[As] a way of reading, (the postcolonial theory) is apt for the interpretation of the ways in which writers express their various forms of contestation with a dominant (discourse). [...] the tools of postcolonial reading are ideal for understanding the forms of transformative resistance in which (the oppressed) engage (Sarangi, 2014:133).

Such awareness is harnessed in the current research to bring to the fore the aspects of the national historiography being challenged by different tropes in the text under study. For a fuller understanding of Vera's meaning in The Stone Virgins, the postcolonial theory is tinged with feminism.

While cherishing the aesthetic quality as a hallmark of literature, feminism in its broad sense, distances itself from abstract dictionbased arguments. It considers as important the discursive strategies that are grounded on plot, characterization and historical setting. This view is aptly demonstrated by Heibrun and Stimpson (1975) in a publication they characterize as 'a dialogue' in which they insist that feminist literature should either be 'an ideological, righteous, angry, and admonitory search' for the errors and sins of the past or 'disinterested and seeking the grace of imagination.' This position demonstrates the importance of historical context while recognizing the potential for aesthetics to achieve a neutral voice which can immensely improve the quality of a text as a commentary. A text should thus exhibit a balance between aesthetics and the need to pass an urgent message as suggested by Heibrun and Stimpson (1975) above. By going beyond the text, the feminist reader avoids lending the voice in the work an indeterminate quality since conclusions arbitrarily arrived at only through the Shklovyskian unlocking of the de-familiarized may render the message incidental rather than intentional. This particular study adopts the African Feminist lens as briefly outlined below.

African Feminism is trajectory of postcolonial or third world feminism. It seeks to dismantle the monolithic and homogenized voice given the woman by western feminism. It maintains that 
women "share with the colonized races an intimate experience of the politics of oppression" as they have always had to contend with male domination in a patriarchal world (Ashcroft et al., 1995:249). However, African feminists are distinctive by striving for recognition not only by the males in their societies but also by feminists in the west. Postcolonial feminism is, therefore, averse to the idea of the universal 'woman'. African feminists insist that even within the Third World, the construct 'woman' is never monolithic. To this end, Schwarz and Ray (2005) point out that African Feminists insist on:

the specificities of race, class, nationality, religion and sexualities that intersect with gender, and hierarchies, epistemic as well as political, social and economic that exists among women. First World feminists are called upon to recognize differences; acknowledge the historical specificity of women in other places and times and abandon their unexamined ethnocentrism... (Mishra, 2013:131).

Awareness of such attributes of African feminism leads the present researchers to search for the presents, in the text under study or otherwise, of discursive strategies that claim space either for 'woman' generally or for 'African woman' in particular.

\section{Can the Subaltern speak without de- sanctifying the memory of the trauma?}

With the official narrative of what has become known as Gukurahundi insisting that both the ruling ZANU PF and the then opposition PF ZAPU were complicit in the violence that unfolded, voices from Matabeleland insist such was not the case. While acknowledging that there were dissident elements from the ZAPU military wing, ZIPRA, critics of the government insist that the dissidents' numbers were negligible and cannot account for six years of the killings that obtained in Matabeleland and the Midlands. To this end, Stauffer (2009:224) maintains that "dissident reality in Matabeleland is contested ground" with glaring disparities not only between numbers acknowledged by the state and those given by organizations such as Catholic Commission for Justice and Peace (CCJP) but also between the ultimate tally at amnesty and the geographical spread of their so-called area of operation. Ultimately, "only 122 dissidents would turn themselves in countrywide" (CCJP, 1997:37) and yet an impression had been made that they were 'here and there and everywhere' at once. Elsewhere, there were unproven speculations that government soldiers masqueraded as dissidents and committed some of the most heinous atrocities under that false identity. There are claims that security forces would get to certain homes by night and demand food as 'dissidents', only to come back the next day and burn, maim and kill people as punishment for supporting insurgents. To the contrary, as earlier noted, President Mugabe (now former), cited in Kostelac (2006:11), is on record as declaring that "we killed each other and both sides were wrong." This not only paints a picture of two equally armed movements butchering each other but also elides the fact that ZAPU leadership not only disavowed the dissident cause but also never ceased to grovel for mercy throughout the whole traumatic episode. The unconditional submission by the ZAPU leadership was matched only by the heightened saber-rattling and the actual execution of violence by the ruling party as some of the officials are recorded calling for the extermination of the Ndebele vermin with DDT (Mnangagwa cited in Coltart, 2016), where DDT refers to the Five Brigade working as a pesticide. In light of such controversies, the fact that Vera ascribes to Sibaso such a destructive role among his own people in the novel may be read as mitigating the culpability of the leadership of the day by spreading the blame for the violence wide and thin. Such a reading 
of the text lends itself to the view that there should be no poetry after Auschwitz (Adorno, 1983) as such work simply never does enough to bridge the yawning chasm between a traumatizing experience of the holocaust, for example, and the aesthetic words that attempt to signify it.

Akin to the foregoing, is the view that giving this much agency in the destruction detailed in the novel to Sibaso plays into the hands of the national meta-narrative that paints a picture of a vulnerable young democracy threatened by heavily armed and sophisticated insurgents. Such a narrative may be read as meant to drown the voices that point out the disproportionate nature of the state's response to the perceived threat of dissidents. It also projects the Gukurahundi enterprise as an altruistic act by the government to save the savage Ndebele from butchering themselves to extinction, an imperial stance borrowed from the colonial script. To the contrary, an analysis of a radio announcement, by the then Prime Minister, Robert Mugabe, soon after the Entumbane (a high density suburb in Bulawayo) riots aptly highlights the ambivalent nature of the incentives for the heavy handed response to what, in hind sight, turned out to have been a minor flare in the fledgling nationstate. The then Prime Minister Mugabe declared:

The government will preserve law and order against disloyal, misguided and politically motivated armed hooligans and political malcontents whose final objective, according to the information before me, is to create chaos and lawlessness so as to pave way for the eventual fall of my government (Yap, 2001:135).

The paradoxical use of language betrays a lack of conviction as to the strength, ideological guidance as well as tactical discipline of the 'malcontents'. Being merely armed hooligans, the malcontents could hardly warrant 5000 , especially trained army troops to suppress and ferret out, even from bellies of pregnant women (CCJP, 1997). Apart from their implied poor training, poor provisioning as well as poor leadership, "...only about 120 dissidents handed themselves in at amnesty (Stauffer, 2009: 227. CCJP, 1997:135 puts the number at 122). Such numbers amongst the dissidents may be deemed not enough to threaten the fall of a whole government. Yet, by giving Sibaso a larger-than-life as well as ubiquitous presence, Vera suggests otherwise. Endowing Sibaso with mystical and enigmatic language, Vera gives this menacing character the ability to exude the strength and invincibility of a rock. $\mathrm{He}$, a dweller of the mountains, insists; "[the] rocks continue in their immortal strength. You are separate. Transient. Human strength rises and wanes [...] the mind is perishable. Memory lingers, somewhere, in fragments" (The Stone Virgins, p.102, emphasis added). By associating human transience with the personal pronoun 'you', and juxtaposing it as binary opposition to his memory-inspired, rocklike immortality, Sibaso inspires such a disconcerting sense of insecurity to the 'other' that any number of soldiers is justified against only four hundred of his ilk. Vera may thus be accused by those who lived through the trauma, and lost limbs and loved ones, of colluding with the meta-narrative whose aim is to justify the unleashing of 5000 super-trained soldiers to weed out hooligans, in their mere hundreds, at the cost of more than twenty thousand lives. Crucially, such a reading also negates the claim that Vera uses The Stone Virgins to stoke tribal flames as her narrative coincides with the official line.

\section{Sibaso: A disaffected Ex-ZIPRA, Super- ZAPU or Pseudo-dissident?}

Another potentially controversial attribute of the character of Sibaso is that he does not adequately represent the concept of 'dissident' 
as understood by the section of Zimbabwean society accused by the meta-narrative of being collectively potentially 'dissident'. Unlike any of the three types of dissidents described elsewhere in this work, he is not killed or captured, nor does he turn himself in at amnesty. Sibaso simply melts into the rocks of Gulathi, wherein he remains at large to date. This aspect of the character, more than any other, highlights the polemic question of who he actually represents. Yet Vera is unequivocal that Sibaso is a disaffected ZIPRA excombatant. That is exactly how the metanarrative explains the concept of 'dissident' in the Gukurahundi context. To the contrary, Stauffer (2009) contends that there are at least four distinct groups who contributed to the aggregate that came to be termed 'dissident'. These include the disaffected ex-ZIPRA combatants, third force elements sponsored by the apartheid South African government as well as 'pseudo-dissidents' comprising either criminal elements or security forces masquerading as dissidents. A brief outline of each of these is given below.

Disaffected ex-ZIPRA members comprised a small contingent of soldiers who took exception to the ZANU PF win in the 1980 elections, those who became victims of the systematic purging from the national army, or those who were integrated into the national army but were later subjected to life-threatening marginalization. According to Stauffer (2009) even highly educated, Russian trained aircraft engineers from ZIPRA only escaped demobilization while the ZANLA personnel understudying them was still learning their ropes. As a third force, Super-ZAPU was trained and sponsored by apartheid South Africa with the sole aim of capitalizing on the chaos in Matabeleland so as to make postcolonial Zimbabwe ungovernable. This would feed the propaganda back south that black on black violence was far worse than colonial rule. The covert project largely recruited from refugee camps commanded by ex-ZIPRA members who had earlier fled to Botswana and South Africa in fear for their lives soon after the chaotic demobilization. The project was code named "Operation Drama" (CCJP, 1997:32). This group met the disdain of 'genuine' ex-ZIPRA dissidents. The CCJP and LRF further aver that among pseudo-dissidents was the gang led by Gayigusu in Matabeleland South responsible for the murder of sixteen missionaries in 1987. This gang was allegedly the personal hit-squad of powerful ZANU officials in the region (CCJP, 1997). Apart from these groups, numerous accounts from victims in Matabeleland indicate soldiers would operate as soldiers-by-day and dissidents-by-night either in search of information or to fan the raging fires of war, or both (Stauffer, 2009). Another incentive for this latter group was to feed the international community with appropriate images to guarantee support for the government in its efforts to stave off a violent insurgence that could, ostensibly, turn Zimbabwe into another raging inferno that Mozambique was. Further support for this claim hinges on Sibaso's language which, it may be argued, ominously issues notice of intent to avenge as he calls "[the] past a repast (and) the future a talisman" (The Stone Virgins, p. 84). Such a reading shows Sibaso, and his constituency, as intending to use the memory of their disenfranchisement (past) to nourish (use as repast for) their unspecified future actions that will work as magic (talisman) in their favor. Against such a background, endowing the character of Sibaso with as much violence, and invincibility, as Vera does and then unequivocally labeling him a disaffected exZIPRA elides the fact that the very identity of what the meta-narrative sweepingly called 'dissident' is highly contested space. Given that there is no record of official ZAPU or popular support for the dissident project. Thus, endowing the silenced with such a discordant voice may indeed qualify as what Adorno views 
as the barbaric writing of poetry after Auschwitz.

\section{Sibaso: A metaphor for the postcolonial rulers!}

Quite contrary to the foregoing, Sibaso could be a metaphor for the nationalist leaders who failed to adjust to their new roles as nation builders but remained trapped in the past, much to the detriment of the present and the future. Read thus, Sibaso's exaggerated sense of entitlement and self-worth could be emblematic of the attitude of the ruling elite. This view is shored up by O'Brien's (2003) suggestion that Sibaso remains a phantom, more a personification of evil than a full-fledged character. Just as Sibaso appropriates Nonceba's body and memory as "[he] holds her dark bone (and) [...] owns her memory" (The Stone Virgins, p. 70-1), so do the new elites impose physical restrictions, thought patterns, pain and death on the new abject subjects. Through unfettered decisions on life or death of any of their subjects, the new elite can show, as they would trophies, the decaying bones of those they exterminate and can appropriate collective memory easily since "many Zimbabweans (are currently) at the mercy of government propaganda [ $\ldots$ and are] force-fed ZANU PF's view of the world" (BullChristiansen, 2004:6). Poisoned by their experiences of the colonial rule, the new rulers cannot lead the new nation-state into the future but hide in the past, rendering their memory synonymous with pain. The new ruler, transmuted in the image of Sibaso, "know(s) how to sleep in the midst of any reality, of several realities. He can inflict harm as easily as he can retrieve it. He has lived to tell many illicit versions of the war" [The Stone Virgins, p73]. Paradoxically, the new rulers cherish their new found freedom and take every opportunity to tout their sovereignty, yet they get the nation bogged down by diverting efforts and resources towards settling old scores. That paradox is echoed by Sibaso with the fidelity of a mirror as he declares himself "a man who is set free, Sibaso, one who remembers harm" (Stone Virgins, 97). When he later charges that "[they] remember nothing" (The Stone Virgins, p. 97), 'they' are the masses of Zimbabwe who did not participate (as armed combatants) in the war that culminated in the liberation of the country as the meta-narrative of the new nation-state has unequivocally rendered such people as non-descript others not entitled to the national cake.

Pursuant to the foregoing is the fact that the war experience for ZANU PF was characterized by a monolithic script of the revolutionary world view. Of note, however, is that the 'tidy revolutionary script' (Stauffer, 2009) does not necessarily suggest an absence of dissent but was symptomatic of a tradition of a form of discipline enforced by brute force. This view is encapsulated in the words of the then Prime Minister, Robert Mugabe, as he reminisced that:

Throughout the war, we have submerged whatever minor contradictions may have existed among us and we have done so out of our recognition of the need to completely destroy the common principle enemy in pursuance of our immediate objective - the establishment of a national democratic state (Stauffer, 2009: 163).

Most ironically, the language in this excerpt suggests that crashing dissent in a postcolonial nation-state is a necessary corollary to the achievement of democracy. Indeed even the most cursory of glances at the ZANU PF's war record reveals a trail littered with pools of the blood of comrades who were sacrificed at the altar for the establishment of a national democratic state. This claim has the support of White (2003) who insists that to submerge the 
Nhari uprisings, the party executed Nhari, Mataure and several others at once while Mutambanengwe, Sanyanga, Mukono and Madekurozwa were sentenced to death in their absence. White (2003: 40) maintains that "(it) is known [...] that many ZANU PF officials who left Zambia, like Mukono and Mutambanengwe, did not return." This paradoxical expression of hate as an inevitable precondition for love is echoed in Sibaso's language as demonstrated below.

Sibaso's idiolect as he rapes and mutilates Nonceba suggests not only his sense of entitlement to such liberties but that Nonceba should accept them as a necessary sacrifice (on her part) for the greater good of the polis. He calls his a quest for "an immaculate truth" which will ultimately lead to the discovery of "a balm (for the country's) wounds" (The Stone Virgins, p. 81). Just as the then Prime Minister Mugabe underscored that the party always quashed dissenting voices for the sacred aim of creating a democracy, Sibaso gives an oxymoronic analogy of the truth being embodied in a type of spider that devours her mate during mating only to use his residue to ensnare her next partner-cum-victim in a vicious circle of fatal love. Sibaso's words are a striking echo of the then Prime Minister's above as the former declared:

Such a spider possesses a valuable secret the knowledge that love cannot be founded on mercy but that mercy can be founded on love. It knows that true agony is ecstasy, that violence is part of the play of opposites, and that during the war there are two kinds of lovers, the one located in the past, and dead, the one in the future, living and more desirable. The past, a repast, the future a talisman. That kind of truth also belongs to the fantasy of a continent in disarray (The Stone Virgins, p. 84).
In these words Sibaso suggests there could have been more freedom fighters coldbloodedly executed by their comrades than by the white settler enemy as suggested by White (2003) in the above submission. Loyalty, as inferred from Sibaso's passage above, cannot be built on mercy but the politics of patronage can guarantee love for, and by, the leader. By referring to a 'healing balm' for the country's wounds, Sibaso makes a bold echo of Enos Nkala, cited in Ngwenya (2014:22) as he declared that "Nkomo and his guerillas are germs in the country's wound and they will have to be cleaned up with iodine. The patient will have to scream a bit (emphasis added)." The inevitability of screaming as a condition of life is also repeated in Sibaso's declaration that love cannot be founded on mercy. Since true agony is ecstasy, the new nation needs to be subjected to as much suffering as possible so as to enable a bountiful harvest of comfort for the elite. By referring to the hurtful past as nourishment for the future which guarantees almost magical success (talisman), Sibaso becomes an emblem of the new elite whose refusal to disengage from the war mode has rendered them trapped in the past, at the expense of the future of the nation. The structure of the sentences in the passage highlight the antithetical parallelisms which, in turn, accentuate the fluid nature of the 'spider's truth'. Through the country's sole television broadcaster, ZTV, the Zimbabweans are regularly force-fed the heroes' 'selfless' gallantry in the face of Rhodesian brute. At other times, the same government mouth piece portrays some of the same heroes as imposters who bought their way safely through the war with currency as dubious as sex.

Similarly, the value attached to violence in Sibaso's language also identifies him with the new rulers as they often boast of being scholars with degrees in the art of violence (Blair, 2002). In the face of unprecedented insubordination from the hitherto kowtowing war veterans, 
President Mugabe (now former) demonstrated in 2016 the extent to which he is willing to harvest (his) 'ecstasy' from the cultural memory of 'agony' as he ominously warned, "Dissidents tried it, and they were war veterans too, and you know what happened" (Mugabe, cited by Kunambura in Financial Gazette of June 10, 2016). Sibaso's word-play regarding the dichotomous lovers of the mate-murdering spider could be Vera's counsel to those in the opposition who are gullible enough to ever think of forging power-sharing deals with the regime. As a lover located in past, Joshua Nkomo, whose total subjugation could have been the primary aim of the Gukurahundi project, was metaphorically cannibalized. He was bullied into a relationship whose consummation culminated in his being devoured by his curious bed-fellow. His pasty remains were made available for use to lure emerging opposition leaders who would prove powerful enough in the future to be desirable as allies. Unbeknown to such future lovers, they too would be fated to be turned into pasty bait in the hands of their mate with which to lure more amorous lovers ready to sacrifice themselves for the longevity of the incumbent dispensation. This claim is given currency by the fact that the novel emerges from an era in which the country was, for the first time since 1980, witnessing the rise of a robust opposition movement in the substance of the Movement for Democratic Change (MDC). The historicity of the text alerts the reader to the fact that the MDC had just handed the ruling ZANU PF its first ever defeat in the hotly contested 2000 referendum (and presumably the 2008 elections). Read thus, Nkomo's (or ZAPU's) political scalp was already safely in the bag and thus literally located in the past. It was then MDC's Morgan Tsvangirai who was to be the target of the same kind of luring (with pasty remains) so as to guarantee ecstasy for the domineering mate. The metaphorical 'pasty remains' could be emblematic of the methods that had seen Nkomo capitulate; protection from brutal persecution (mercy) founded on an earlier show of the sheer brute force of such persecution (love). With the benefit of hindsight, it may be argued that the vicious circle against which Vera warned did unfold with the formation of the Government of National Unity in 2009 in which the MDC, like ZAPU before it, only served to nourish the ruling ZANU PF which emerged from the arrangement stronger than it was when it entered. Such a reading renders Vera as appropriating cultural memory in her quest, as a novelist, to play society's sentinel.

\section{Sibaso: A compromise to blur the line between tribes!}

Sibaso's violent disposition could also be Vera's effort to demonstrate how Zimbabwe, as a new nation-state was poisoned by postcolonial mimicry. As viewed by Bhabha (1994) postcolonial mimicry, more than any other attributes, renders revolutionary transformation most elusive because it entails embracing the former master's mode of operation in ways that lead to total disavowal of the aspirations underlying the revolution. The argument is put more incisively by Fanon (1963:75) who contends that "[the] program (revolutionary transformation) consists of not only climbing out of the morass but also catching up with the other nations using the only means at hand." The 'means at hand' being the oppressive system of production inherited from the colonial master. Fanon insists that the new elites conclude that the colonial masters achieved the kind of success that they did on account of the efficiency with which they managed the means at their disposal. Thus convinced, they set out to prove to themselves, and to the world, that they are capable of the same achievement all on their own. It is with such a frame of mind that individual liberties and rights get 'submerged' in the interest of 'successful' national sovereignties. This view is reflected in Sibaso's words as he characterizes "Independence (as) 
the compromise to which (he) could not belong. They never speak of it now; at least [he does] not hear of it" (The Stone Virgins, p. 97). In this passage Sibaso clearly delimits between ' $l$ ' (him) and 'they', suggesting his character is not part of trope representing the elite but emblematic of the 'others' disappointed with the superficial change at the level of the color of the oppressor's skin while the rest of the oppressive infrastructure remains in place. $\mathrm{He}$ terms independence a 'compromise' suggesting it is some kind of collusion between the former and the current rulers to prolong the subjugation of the masses. The ' $l$ ' and 'they' binaries strongly suggest his agency in not being part of the compromise. The fact that Vera allows Sibaso and Nonceba to alternate in their narration of their gruesome encounter accentuates the notion that she deliberately allows Sibaso to maintain a nebulous distinction as both victim and culprit, a discursive strategy which renders her unwilling to create the binaries of 'the good' and 'the evil' (at the level of ethnicity) in the traumatic memory she seeks to keep alive. Such a reading ought to absolve Vera of the charge that she stokes the flames of tribal tensions, as the binaries she creates are at class rather than ethnic level.

Another flash point in Sibaso's identity is his identification of Nehanda as his ancestor. The name 'Sibaso' is Zulu for kindling or "a flint to start a flame" (The Stone Virgins, p. 73). His name suggests he is ethnic Ndebele. This identity is also buttressed by his location in the ex-ZIPRA dissident camp, which is defined by the meta-narrative as exclusively Ndebele. Yet at arguably his most vulnerable moment, Sibaso counts the ancestors he can trust on his fingers and amongst them is Nehanda. He is bold enough to face a tumultuous city because "she protects (him) with her bones" (The Stone Virgins, p. 107). Through that act by Sibaso, Vera takes a bold step away from the longentrenched view of Zimbabwe as populated by ethnic groups relating to each other on the 'us- versus-them' basis. If pre-colonial binaries of victor (Ndebele) and vanquished (Shona) were expertly exploited by the colonizer so as to stoke the suspicion that negated (almost totally) the possibility of the cooperation that could only be built on trust between the country's major tribes, postcolonial mimicry ensured that the ZANU PF government inherited the strategy in order to keep the masses too preoccupied with hating each other to question the service they got from their leadership. This involved labeling Ndebele as rebels and rabble-rousers and Shona as heroes. Among some silenced aspects of the contributions of Ndebele ethnic group to nation building in Zimbabwe is the elision of that group's heroes from both the First and the Second Chimurengas. By allowing Sibaso to claim as his ancestor the revered Shona figure of Nehanda, Vera renders ever so blurred the line between tribes and transcends the petty polarization of Zimbabwean society as good - bad, or guilty - innocent based on tribe. She brings to the fore the fact that as was the case during colonial occupation, emphasis on those issues that separate people according to tribe at the expense of those that unite them only serves the interest of the manipulative elite. Such a reading places Vera beyond the reproach of those who claim her text only stokes tribal conflict.

Contrary to the above submission, the Zimbabwean subaltern may wonder if Vera, through Sibaso's relationship with Nehanda, argues convincingly on behalf of the absent witness-cum-victim. In a contribution aptly titled "In the presence of the absent: Rebecca Belmore's Art of Witness", Lauzon (2008) echoes Adorno's (1983) injunction that there should be no poetry after Auschwitz (traumatizing experiences) by highlighting the ethical problems that are raised by any attempt to incorporate into cultural memory "events whose witnesses are unable - and unavailable - to represent themselves" (Burke et al., 2008:17). As Lauzon's title suggests, the 
literary artist's work needs, for ethical reasons, to be such that the artist can retell her version of events, even if the absent witnesses were present, without being called out for understating those victims' cases. Similarly, the Ndebele heroes who contributed to the building of present-day Zimbabwe but are elided by the meta-narrative, would, if Vera's character was speaking in their presence, wonder why Sibaso squanders the opportunity to sing the unsung heroes of his society while exalting an already over-sung heroine who has no lack of praise singers. They may wonder why Vera allows Sibaso to claim a Shona ancestor on behalf of the Ndebele community that he seems to represent in the text. Through such lenses, a postcolonial novelist can only produce work that is haunted by the traumatic experiences but will always fall short of representing what remains an unknowable and untranslatable experience.

\section{The Virgins with stone-girded loins}

While the novel clearly bemoans the blatant alterity of the female under several layers of oppression in the postcolonial space, with the female assigned the unenviable role of contributing to the war effort only as the turf on which rape, mutilation, decapitation and unrestrained bloodletting unfolds, Vera makes a gallant attempt to negotiate for the veneration of the woman in The Stone Virgins. While the characters of Thenjiwe and Nonceba epitomize the woman located at the confluence of violence and marginalization, as well as at the mercy of the brute force that has a male face, the appearance of female soldiers at Sondela Assembly Camp redeems that miserable status. They become a symbol of the strength and self-determination and are far removed from the female figure who serves as cannonfodder and the helpless target of rape, mutilation and decapitation. These gallant women are juxtaposed with "city men (who) lose their swagger and fall to their knees as the women, newly returned from the war, (...) call out for cigarettes in idle tones" (The Stone Virgins, p. 121). The only woman that these city men have always known to be free, and 'human' (read as man) enough to smoke cigarettes, is the white woman. Even she would only smoke the mild Everest brand which is especially tempered to tolerate her delicate lungs. To the contrary, these stone women, rough-hewn from the rocks of Gulati, only demanded "Madison for some, Lucky Strike for another (and none) asked for Everest" (The Stone Virgins, p. 121). Read thus, Vera diminishes the line between masculinity and femininity to a nebulous blur.

Vera strongly belies the rampant innuendo abound in the metanarrative that even the most revered women soldiers only contributed to the war effort by keeping the real heroes warm at night. State-run media once serialized the late George Rutanhire, former commander during the war, sensationally denigrating former Vice President Joyce Mujuru for having been "a lazy sex monger during the war [...] and a serial bed hopper who got promoted for her sexual relationships with commanders" (Dewa, 2016). Rutanhire goes on to claim that rather than being an asset, women soldiers were a liability whose escapades cost the lives of heroes such as Chipembere who was surprised by a Rhodesian attack "during the intercourse, [forcing him to fight] the better part of that battle while he was naked" (Dewa 2016). Vera refutes such claims as slanderous through an enigmatic presentation of the women soldiers at Sondela Assembly Camp. She reveals that the "women are said to sleep in their whole attire, in those boots - [as] along with them are four hundred other soldiers living within the barbed wire fence which surrounds their camping ground" (The Stone Virgins, p. 119). Apart from highlighting their perpetual state of readiness to spring to action along with the other four hundred, 'their whole attire' also serves as chastity belts which locate the women soldiers in a realm that transcends mere sex toys for the 
'others'. Whereas the male narrative claims that some women combatants even obstructed the war efforts with their loose skirts, these virgin heroines have their loins girded in stone allnight. The mystical demeanor of the virgin heroines is further accentuated by the fact that even the omniscient third person narrator assigned to this particular chapter by Vera is careful not to give the impression of being privy to the goings-on inside the heroines' tents as the narrator makes it clear that knowledge of what happens inside the heroines' tents is owed only to what is 'said'. This further entrenches the sanctity of the privacy of those tents. Such a reading negates claims by the male war veterans, through state information infrastructure. Vera thus negotiates a place of honor for the heroines of Zimbabwe's liberation struggle.

Akin to the foregoing, Sihle, a single mother of four with the same man, is another symbol of the chaste nature of the self-determination of the women as portrayed by Vera. She is not married to Ndabezinhle Dlodlo but relates with him on her own terms. They have sired four sons together on her own terms yet "in the mouths of all the people of Kezi, they are as married as if they lived together" (The Stone Virgins, p. 102 emphasis added). The sanctity of their marriage in the eyes of all, including the other man of Kezi, attests to the fact that none other than 'sekaZenzo' has ever been allowed to undo the girdle around her loins. Yet it is all on her terms as "Sihle refuses to leave the home in which she was born" (The Stone Virgins, p. 102) as she is sure she would not hesitate to leave Dlodlo in misery should there be a negative "desire that has decided to visit his tongue" (The Stone Virgins, p. 103). Sihle thus epitomizes a "recognition and presentation of the African woman as the subject and not the object [...] and as agents in their lives and societies" (Charter of Feminist Principles for African Feminists [CFPAF], 2006:11). Further support for the claim of chastity for Vera's women characters is drawn from the fact that although Thenjiwe instantly falls in love with the traveler from the east, she is, by Cephas Dube's account, so pure that her nakedness "has never breathed the sun, never breathed the day; no one has ever laid eyes on it but (him)" (The Stone Virgins, p. 38). In her sojourn at Cephas' place, Nonceba's quest for a room of her own sees her perform a ritual almost akin scent-marking as she enlist the former's help to nail a painting at a "perfect" level (by her reckoning) so that the "room is now completely hers" (The Stone, Virgins, p.153). The fact that she performs this 'scent-marking' even as she is guest at Cephas' charity, is testimony to the fact that she claims, and accepts, that charity in her capacity as a person and not as one who can use her sexuality to charm her way through life. Like Nonceba, the other two major female characters, each in her own way, make a bold feminine statement. Pure as she is declared to be by Cephas, Thenjiwe is bold enough to be buoyed by "her weightless courage to be loved" (The Stone Virgins, p. 29) to "bring home the man who gives her all her hips, who embraces her foot, who collects her shadow and places it right into her body as if it were a missing part of herself" (The Stone Virgins, p. 33). This way she claims her "right to a healthy, mutually respectful and fulfilling personal relationship" (CFPAF, 2006:11). Similarly, by insisting on her agency in her life while faithful to one man as a sexual partner, Sihle affirms the African feminists' principle that the fight for rights and space should not be synonymous with slovenliness. Vera thus uses these characters to replace the shadow that has hitherto been stripped off the body of the Zimbabwean woman by the male narrative of the war.

\section{Nehanda: A citadel occupied and defiled by a gun-slinging tyrant!}

Arguably the most poignant trope in The Stone Virgins is Vera's rejection of the appropriation of Nehanda's bones in war cries often chanted, 
with cruel irony, simultaneously with the perpetration of the most heinous crimes against women and children. It may be argued that the title 'the stone virgins' is a protest against the portrayal of Nehanda as "the frozen image" (Hunter, 1998:77) who, by being cast in stone, is rendered more vulnerable to manipulation. Nehanda's place of honor in the hearts and minds of the majority of Zimbabweans makes it almost a sacrilege to stand against anybody who evokes her name, and quite sadly, the national narrative is seen as bleeding that reserve of goodwill dry. In her earlier text, Nehanda, Vera writes the iconic heroin in and out of the national narrative. However, in The Stone Virgins, Vera "is explicitly critical of the ways in which Nehanda's legacy has been placed in service to a nationalist discourse and practice that is revealed [to be] murderous to women" (Mkwesha, 2016:20). This shift in tone is brought to the fore in the passage in which Vera allows her readers to witness the demise of the short-lived and fragile, yet euphoric, façade of independence as she reveals:

The war begins. A curfew is declared. A state of emergency. No movement is allowed. The ceasefire ceases. It begins in the street, the burying of memory. The bones rising. Rising. [...] Independence ends. Guns rise. Rising anew. In 1981 (The Stone Virgins, p. 59).

In this passage Vera, like her character Sihle, 'mourns a lullaby' which is conspicuous by being loud enough to traverse celestial distances and yet it allows some to snooze even at its crescendo. The staccato rhythm created by her short poetic sentences reveals her horror at, and aversion to, the betrayal that confuses the rising guns to Nehanda's bones rising anew in 1981, long after the colonizer who buried the heroine in a noose had left. This parodies Nehanda's iconic 'promise,' even as she gallantly wore the noose; that her bones shall rise and consecrate what the shameless hand of the colonizer had desecrated. Like many other heroes and heroines in postcolonial Zimbabwe, Nehanda is thus being appropriated as the pasty remains of the mate of Sibaso's cannibalistic spider to lure "the (lover located) in the future, living, and more desirable" (The Stone Virgins, p. 84). The dirge-like poetic rendition invites the reader to share Vera's horror at the realization that by sullying such a solemn and ancient promise, the new rulers declare all the other promises and allures of independence as null and void. They suspend indefinitely all hope, through their "burying of (a) memory" (The Stone Virgins, p. 59) that has fed the flames of the revolution.

Akin to the above is that even after his revolting violence on the female body, Sibaso evokes the name of a female ancestor as the last line of his defense against a world gone hostile and convoluted. He feels alone in a world gone awry, where "reality stops coinciding with (his) wishes" (The Stone Virgins, p. 107). After years of living in the safety of the hills of Gulati, Sibaso is at his most vulnerable in a city of total strangers, with each of those a potential enemy as he is on a mission to reclaim what his family owned before the war. It is tantalizingly flattering that of all his ancestors, the female one ranks among his most trusted five. However, the background of the vile deeds that Sibaso commits against the nurturing female body even as he says these words renders acerbic his claim to the protection of "[the] one buried in a noose, Nehanda, the female one" (The Stone Virgins, p. 107). He, and all those he emblematizes, is projected as a gun-slinging murderer baying for the blood of the unarmed women from the very bowels of the citadel that ought to have been the latter's last sanctuary. As a further slight to the "right of all women to live free of patriarchal oppression, discrimination and violence" (CFPAF, 2006:10) is the fact that the 'noose' which Nehanda was buried in was put around her neck by men 
protecting 'certain entitlements' and protesting 'unspecified infringements' at the onset of colonialism. At the perceived end of colonialism, the very men who evoke her name for protection also wreak unprovoked violence on Nehanda's archetypal progeny. Nehanda is thus "a woman of stone" (The Stone Virgins, p. 130 ) in a very negative way. She is a being with no emotion, no entitlement, no opinion, no memory and, therefore, no rights. Quite contrary to its superficial portrayal of the African woman as at par with mother-nature herself, who nurtures both prickly thorns as well as fruit bearing trees, this reading renders Sibaso and his ilk as moles who callously devour the very walls of the womb that nurtures them. Vera thus uses Nehanda's name as a strong rebuke to postcolonial Zimbabwe's treatment of women.

The foregoing claim draws support from Sibaso's portrayal of his mother. He reveals that he was born of a dead mother. Traditional African folklore in Zimbabwe holds it as axiomatic that during the all-too-often child birth complications, the choice between sacrificing 'self' or the unborn child lies with the mother. It is also true that the norm, encouraged especially by western medicine, is to save the mother, as WHO insists that 'no life should be lost while giving life.' It is viable speculation that those involved in Sibaso's birth not only tried to save the mother when the process got complicated but also encouraged her to make it is easy for them to do so. Yet, by Sibaso's own account, his mother literary gave birth to him long after she had already died. He insists that "when [he] was born [his] mother had already died" (The Stone Virgins, p. 107). Sibaso was not 'cut out of his mother's body' but was born by his dead mother. Defying the violent intrusion into the female body in search of the unborn baby that would later characterize the Gukurahundi era, whereby "[some]pregnant women were accused of carrying dissidents and would have their stomachs ripped open to reveal the dissident they were carrying" (Blair,
2002), Sibaso's mother negates the availability of the caesarian delivery and gives birth in death. Whatever last ounce of energy her body could still summon, Sibaso's mother devotes to enabling Sibaso to swim "out of her body which flowed like a river" (The Stone Virgins, p. 107). At a superficial level, Sibaso's reference to the fateful circumstance of his birth may read like a tribute to the African mother. However, his mother's self-sacrifice accentuates the tragedy that, of his agency, Sibaso would later not only rape, decapitates and mutilates his mother's archetypes but also be "(the) flint to start (the Gukurahundi) flame" (The Stone Virgins, p. 73) that would culminate in the murderous cutting of fetuses out of their mothers' bellies in postcolonial Zimbabwe. As further argued below, Sibaso's reference to his mother's sacrifice of her life to give his is by no means an ode to the African mother.

Pursuant to the foregoing, Sibaso's claim that he swam out of his mother's body may be a manifestation of Vera's disdain at society's blatant disregard for, or claim of entitlement to, the woman's sacrifice. While clearly conceding that he 'was born' by his already deceased mother, he goes on to claim agency for his 'escape' out of the dead body as he "...swam out of her body which flowed like a river. It is this to be alive. I am among the drowned, those with a feline imagination" (The Stone Virgins, $p$. 107). Sibaso thus locates the agency for his being alive in his conscious act of 'abandoning' his mother's failing body at the opportune moment. He thus claims for himself the legendary nine lives of the cat, having already lived beyond a 'drowning.' Read thus, instead of being grateful to his mother for the sacrifice of her life for his, he gleefully gloats at having survived the 'betrayal' that cost him one of his cat-like nine lives. This claim partly hinges on the fact that one of the characters who is emblematic of the "hyper-visible invisibility of the [woman]' (Lauzon, 2008:76) in Vera's text, Sihle, has the undeserved notoriety of being 
responsible for whatever goes wrong in her extended family. As Nonceba reveals:

It is Sihle who is blamed for everything the women of the Gumede family fail to do or do improperly; talking to strangers, our inability to secure husbands, and stubbornness, blamed by the men in the family, that is. And at such times Sihle is referred to in the most polite term, naZenzo (The Stone Virgins, p. 103).

Such a characterization of the female 'other' in Sibaso's society makes very feasible the claim that he blames his mother for the unfortunate circumstances of his birth while harvesting all the glory for the fact that at least he survived. In the above passage, Sihle's highly visible invisibility is accentuated by the fact that it is only when she is being chastised for some perceived flaw, most likely attributed to her being a woman, that she is called by her first son's name. At best, her given name is viewed as insufficient and unworthy of the gravity of the matter at hand or, at worst, her brother Mduduzi cannot suffer the indignity of belaboring a female name with his 'whip' of a voice when the stakes are as high as the 'honor' of the family. Read thus, Vera is calling society out for reserving nothing but contempt for the woman.

Further commentary on society's culpability to the horrors that are visited upon its women folk in The Stone Virgins is Vera's choice of who gets to be the first on the scene of Sibaso's carnage. During the attacks, Nonceba hears "human voices (but) they are far away, too far, away [to hear her]' (The Stone Virgins, p. 100). Only Sihle, the scapegoat for all that goes wrong with the women of the Gumede family, is the first to discover the atrocious trail left behind by Sibaso. Aware of her 'inadequacy' [being only Sihle] in dealing with matters of such magnitude, she calls "....all the names of her [male] children as though the existence of their names in our midst will attend to our http://escipub.com/american-journal-of-educational-research-and-reviews/ desperation. She moans a lullaby that flows from the sky to the earth" (The Stone Virgins, p.103, emphasis added). The cry, celestial in proportion, is enough to wake all the dead ancestors but only serves as a lullaby for her sons, who are content to merely lend the occasion the 'dignity' of their names. Mduduzi's 'whiplash' of a voice may be effective in putting naZenzo in her place, but it fails to exorcise the ghost of Sibaso's voice as it superimposes the latter's version of events in Nonceba's mind. Through her elliptic language, Vera leaves her readers wondering whether Sibaso is still physically present in this scene or he is only a voice in Nonceba's traumatized mind. This style also leaves open the possibility that the frantic inquiry into what has happened that Nonceba attributes to Sibaso may actually be from any of the male members of the Gumede clan. Such a reading of this episode is encouraged by the similarity between Mduduzi's voice which is "like a whip" to Sibaso's, which "makes every other sound perish" (The Stone Virgins, p. 103). Such an ambiguity renders very blurry the distinction between Sibaso (as a trope for the invading Gukurahundi) and the Gumede men (emblematic of the males of the Ndebele society), thus serving to further accentuate Vera's indictment of the male half of society, without regard to tribal affiliations, for complicity in the carnage that the Gukurahundi enterprise leaves in its wake.

\section{Cephas Dube: The muzhanje (wild loquat) tree begrudgingly takes root in alien soil and bountifully feeds the famished natives}

Cephas Dube can be read as a big part of the feminist trope in The Stone Virgins. Unlike various forms of extreme feminism, African Feminism acknowledges some space for a man in a woman's life. CFPAF (2006) acknowledges the right to healthy, mutually-respectful and fulfilling personal relationships. In his first appearance in Kezi, Cephas Dube seems to fall totally in love with Thenjiwe's body and expects 
her to be satisfied with him as symbolized by the single mazhanje (wild loquat) fruit in his 'pocket'. This creates a dichotomy as Thenjiwe gets interested in the whole muzhanje tree, particularly its roots. "She wants to know the shape of the roots of this tree (as she) ....knows that roots of trees have shapes more definite than leaves" (The Stone Virgins, p.37). If the mazhanje fruit emblematizes what Thenjiwe can enjoy momentarily from her relations with Sibaso, then by going beyond the fruit and focusing on not only the tree, but also its roots, Thenjiwe communicates an enduring interest in the person of Cephas Dube as well as his family, community and entire culture. This is an attitude which suggests a willingness to commit to a lasting relationship. This not only scares Cephas, but also annoys him. His initial strategy is to get along with Thenjiwe's obsession with the tree and its roots as this feigned interest "is rewarded by sudden" (The Stone Virgins, 37) personal gratification. He balks, however, when he realizes that this only feeds her determination to look beyond the present into the future which, for her, seems to belong with his roots. The asymmetrical nature of their relationship is brought to the fore by Thenjiwe's willingness to bare her soul (signified by the iconic Kezi marula tree) to him. As Thenjiwe muses:

She would start, perhaps, with the marula tree. She wants to discover the shape of its roots and show them to him till these roots are no longer under the ground but become the lines planted on his palms, each stroke a path for their dreaming (The Stone Virgins, p. 41).

Cephas himself gives testimony of the purity of her intentions as he suggests she only surrendered her virginity to him since it was he who stripped the bark to reveal a "stem so pure [...] no single speck of dust has been near [it]" (The Stone Virgins, p. 38, emphasis added).
Yet in spite of all that she sacrifices, that sacrifice is not mutual as he withholds the details of his roots.

However, Vera redeems Cephas from his carnally defined notion of love as he latter accords Nonceba 'a room of her own'. Vera makes a bold statement on the possibility of men offering women a brotherly shoulder to lean on with no strings attached. The reader is at first curious as to the real motivation behind Cephas' interest in Nonceba as he confesses he wants to help her "perhaps for (his) own sake" (The Stone Virgins, p. 142). Background knowledge of his carnality encourages the reader's imagination to run as wild as it can. However, Cephas' feelings of guilt for failing to recognize Thenjiwe for what she was worth, thus abandoning her to the morbid fate that overtook her, becomes apparent as her absence continues to be a bold presence. Vera reveals "(he would often look) up at someone else in the room, not Nonceba" (The Stone Virgins, p.146). This attitude stokes intrigue as he seems to be using Nonceba as a tool to retrieve his errant past. Cephas, though, continues to get convincing in his noble intent to help Nonceba get up on her feet once again even as she also helps him come to terms with his loss. However, the reader's fascination with Cephas Dube's intentions turns into anxiety as "Nonceba grows on him like a good song" (The Stone Virgins, p. 158). The anxiety is premised on the fear that Cephas could allow his "desire (which) is like hunger" (The Stone Virgins, p. 162), to disregard Nonceba's delicate disposition owing to her traumatic experiences. As "his (desire) begins with a hurt so enormous he cannot contain it" (The Stone Virgins, $p$. 162), the reader bats his/her breath and is ready to forever abhor and despise Cephas should he handle himself in a manner even remotely likely to cause Nonceba to relive her horrible experience at Sibaso's hands. Cephas thus earns the great admiration of the reader when he declares his resolve that "[if] there is to 
be any pain now, he is the one to bear it" (The Stone Virgins, p. 164). The reader's celebration of Cephas as an iconic human is accentuated by awareness of the passion with which he has grown to desire Nonceba and yet he has the presence of mind not only to restrain himself but also to "wait till Nonceba turns to him with a wonder to match his own, with an equal wish" (The Stone Virgins, p. 162). Determined to break his notoriety of walking away from situations that challenge him, Cephas declares "he would not walk away [this time]" (The Stone Virgins, p. 164). Cephas thus upholds the CFPAF (2006:11) by his "recognition and presentation of African women as subjects not objects [...] and as agents in their lives and societies." That recognition of Nonceba as a subject and an agent assures Cephas that, as long as he remains deserving, then Nonceba, in her own good time, will recognize and respond to his yearning.

Cephas Dube may be Vera's proposal for the way towards national healing in postGukurahundi Zimbabwe. With a first name (Cephas) of European origin and a surname (Dube) common among both Ndebele and Shona, he is clearly proposed by the novelist as ethnically neutral. The Mazhanje seed that was treasured by Thenjiwe in his first appearance in the novel locates Cephas Dube's roots in the soils of Chimanimani. However, Kezi itself, as one of the novel's major setting, is home to many with the surname 'Dube'. As such, Vera seems to deliberately confer on the character of Cephas Dube a nebulous ethnicity. As proposed elsewhere, by creating both victim and culprit in Sibaso, Vera sets out to diminish the location of tribes in the binaries of good and evil. It may also be argued that Cephas Dube is a metaphor for the identity of those responsible for the "deliverance" (The Stone Virgins, p. 165) of the type that Nonceba (a trope for the traumatized society) receives from Cephas Dube. Just as Cephas Dube transcends tribal and even racial identity, so is the responsibility for healing. The magic formula proposed by scholars on conflict resolution is "...a genuine expression of regret and remorse for the harm done" (Tavuchis, 1991:8). However, critics of the view that apology alone is enough insist "it is a myth to presume it [apology] automatically [heals]" (Van Zyl, 1999:16). Mere acknowledgement of responsibility may not be enough as cynics may view it as "lip service and empty rhetoric, $[. .$.$] a cheap and easy way$ for perpetrators and their descendants to assuage their guilt" (Barkan and Karn, 2006:8). Rather, a sincere expression of contrition has to be offered not only in the right tone but also accompanied by restorative justice. Cephas Dube comes across as if he is following a script prepared by Barkan and Karn (2006), since his is a quest to genuinely, and as unobtrusively as possible, help Nonceba get back on her feet. In his nebulous ethnic as well as racial guise, he [as a trope] observes no sacred cows. He reproaches male hegemony in general and the ruling elite (Dube of eastern Zimbabwe) in particular, for failing to acknowledge the wrongs of the past as a prerequisite for an inclusive future. He also calls out the Matabeleland society (Dube of Kezi) as he insists on the evacuation of the psychological "Kezi, a naked cemetery where no one is buried and everyone is betrayed" (The Stone Virgins, p. 142). He chastises the former colonial power for exaggerating ethnic tensions during colonial period and for not lifting a finger during the Gukurahundi massacres. Through Cephas Dube, Vera thus places the onus on Zimbabweans of all creeds, as well as the international community, for the possibility of true healing.

\section{Conclusion}

The article asks the key ethical question as to whether Vera, having branded her novel an alternative to the national historiography, does justice to the society that lived the traumatizing experience. On one hand, the discussion 
sought to establish how much of the novelist's account coincides with the views of the subaltern from the affected area and how much risks were being taken to entrench the metanarrative. Towards that end, Sibaso's fluid status as a victim and a culprit was investigated. As a dissident, Sibaso is juxtaposed with what the voiceless that Vera claims to speak for define as constituting the concept of dissident. Controversy is also raised on whether Sibaso's claim on Nehanda as an ancestor does not assist the meta-narrative which maintains that Matabeleland has a dearth of heroes from both the First and the Second Chimurengas. On the other hand, Vera's commentary on the historiography of Zimbabwe as a postcolonial state in general, and of the Gukurahundi massacres in particular, is vetted for fairness. An attempt was made to establish whether the novelist is a mischievous rabblerouser intent on stoking tribal tensions and subverting the legitimacy of the new elite. Towards that end, the character Sibaso is proposed as a trope for the postcolonial dispensation that seems to be trapped in the past that equates memory to pain and agony to ecstasy. His language and actions are juxtaposed with those of the heroes of postcolonial Zimbabwe. This approach assists in analyzing whether Vera not only lends the appropriate voice to the voiceless but also whether her commentary on the new nation state seeks healing or merely rubs the wounds to keep them raw.

\section{References}

\section{Primary source}

Vera, Y. (2002). The Stone Virgins. New York: Farrar, Struass and Giroux.

\section{Secondary sources}

Adorno, T. (1983). Cultural criticism and society. Prisms (pp. 17 - 34). Cambridge MA: MIT Press.

Ashcroft, B., Griffiths, G. \& Tiffin, H. (Ed) (1995). Postcolonial Studies Reader. New York: Routledge.
Barkan, E. \& Karn, A. (2006). Taking Wrongs Seriously: Apologies and Reconciliation ( $1^{\text {st }}$ Ed). Stanford: Stanford University Press.

Bhabha, H. (1994). The Location of Culture. London: Routeledge.

Blair, D. (2002). Degrees in Violence: Robert Mugabe and the Struggle for Power in Zimbabwe. London: Continuum.

Bull-Christiansen, L. (2004). Tales of the Nation: Feminist Nationalism or Patriotic History? Defining National History and Identity in Zimbabwe. Gortenborg: Nordiska Afrikainstitutet.

Burke, L., Faulkner, S. \& Aulich, J. (2008). The Politics of Cultural Memory. New Castle: Cambridge Scholars Publishers.

Catholic Commission for Justice and Peace and Legal Resources Foundation (1997). Breaking the Silence, Building True Peace - A Report on the Disturbances in Matabeleland and Midlands 1980 1987. Harare: CCJP and LRF.

Charter for Feminist Principles For African Feminists[CFPAF] (2006). The African Feminist Forum. Accra: African Women's Development Fund.

Coltart, D. (2016). The Struggle Continues: 50 Years of Tyranny in Zimbabwe. Auckland Park: Jacana.

Derrida, J.J. (1994). Specters of Marx: The State of Debt, the Work of Mourning and the New International. Trans. P. Kamuf. New York: Routledge.

Dewa, T. (2016). "Zim's Liberation War Narrative Confusing." In The Financial Gazette, 1 September, 2016.

Dickinson, E. (1924). "Tell All Truth, but Tell it Slant." In R. N. Franklin (Ed). The Complete Poems of Emily Dickinson. Harvard: Harvard University Press.

Heibrun, C. G. \& Stimpson, R. C. (1975). "Theories of Feminist Criticism: A Dialogue." In J. Donovan (Ed.). Feminist Literary Criticism. Lexington: University Press of Kentucky.

Hunter, E. (1998). Shaping the Truth of the Struggle. Current Writing: pp.75-86.

Fanon, F. (1963). The Wretched of the Earth. Trans. C. Farrington. New York: Grove Press.

Kostelac, S. (2006). Poetic Language and Subalternity in Yvone Vera's Butterfly Burning and The Stone Virgins. Johannesburg: University of Witwatersrand.

Kanumbura, A. (2016). Mugabe Threatens War Veterans. The Financial Gazette, June, 10, 2016. @ www.fingaz.co. zw (accessed May 18, 2017).

Lauzon, C. (2008). "In the Presence of the Absent": Rebecca Belmore's Art of Witness. Burke, http://escipub.com/american-journal-of-educational-research-and-reviews/ 
L., Faulkner, S. \& Aulich, J. (2008). The Politics of Cultural Memory. New Castle: Cambridge Scholars Publishers. Pp.76-91.

Mishra, K. (2013). Postcolonial Feminism: Looking into - within - beyond - to Difference. InAcademic Journals Vol. 4(4), pp.129-134.

Mkwesha, F. (2016). "Zimbabwean Women Writers from 1950 to the Present: Re-creating Gender Images. PhD Thesis, Stellenbosch University.

Mupondi, A. (2013). Book Review. Sign and Taboo. Perspective on the Poetic Fiction of Vera. A TRIBUTE TO ZIM'S LATE WEAVER OF WORDS. Africana Vol. 6(2), pp. 217 - 224.

Mzali, I. (2011). Postcolonial Readings of Resistance and Negotiation in Selected Contemporary African Writing. Montreal: University de Montreal.

Narayan, R. K. (1943). Tales from Malgudi. New York: Penguin.

Ngwenya, D. (2014). Healing the Wounds of Gukurahundi: A Participatory Action Research Project. PhD Thesis. Durban University of Technology.

O'Brian, E. (2003). 'Stone of the Heart' @ http://www.newyorke r.com .html (accessed on 10 October 2017).

Sarangi, J. (2014). Rethinking Postcolonialism: An Interview with Bill Ashcroft. Studia Anglica Resoviensia. P.85

Schwarz, H. \& Ray, S. (Eds.) (2005). A Companion to Postcolonial Studies. Oxford: Blackwell Publishing Ltd.

Stauffer, C. S. (2009). "Acting out the Myths: The Power of Narrative Discourse in Shaping the Zimbabwean Conflict of Matabeleland, 1980 - 1987." Unpublished PhD Thesis.

Tavuchis, N. (1991). Mea Culpa: A Sociology of Apology and Reconciliation. Stanford: Stanford University Press.

Vambe, M. T. (2004). African oral story-telling tradition and the Zimbabwean novel in English. Pretoria, South Africa: UNISA Press.

Van Zyl, P. (1999). "Dilemmas of Transitional Justice: The Case of South Africa's Truth and Reconciliation Commission." In Journal of International Affairs 52.2: 1-21.

Veit-Wild, F. (2006). De-silencing the Past Challenging Patriotic History. New books on Zimbabwean Literature. Research in African Literatures 37(3), pp.193 - 204.

Vera, Y. (1993). Nehanda. Harare: Baobab Books.
White, L. (2003). The Assassination of Herbert Chitepo - Texts and Politics in Zimbabwe. Bloomington: Indiana University Press.

Yap, K. (2001). Uprooting the Weeds - Power, Ethnicity and Violence in the Matabeleland Conflict 1980 - 1987. In Elanders Novum, p.35.

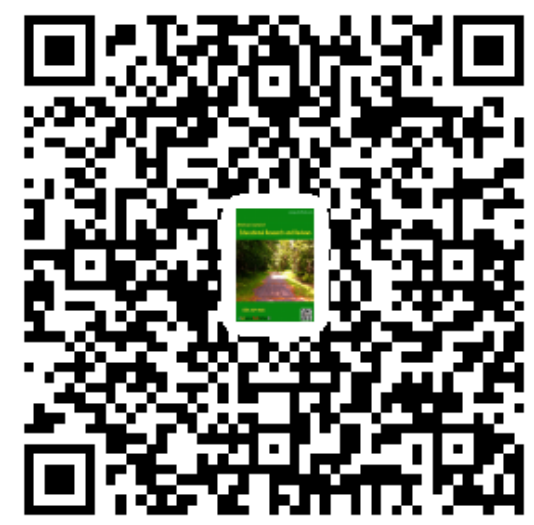

http://escipub.com/american-journal-of-educational-research-and-reviews/ 